\title{
Do Downsizing and Global Financial Crisis Affect SMIs Labour Productivity in Malaysia?
}

\author{
N. A. Ibrahim, R. Suhaimi, and F. N. Chong
}

\begin{abstract}
This paper examines the effect of downsizing and global financial crisis on the labour productivity of the manufacturing industries in Malaysia. Due to the crisis, many industries retrenched their workers to adjust to the declining demand in their respective industries. Two distinctive subindustries that have the highest retrenchment rates are the manufacturing of radio, television and communication (27\%) and the manufacturing of rubber and plastics $(13.3 \%)$ out of total retrenchments within the last three years $(2009-2011)$. The main reason for the downsizings is the deteriorating demand for their products. Using panel data analysis with fixed effects on monthly data from 2003 till August 2011, the study finds that the global financial crisis has positively affected labour productivity of the SMIs but it has negatively affected the large ones. Downsizing activities among the SMIs did not have a significant impact on labour productivity of industries in general.
\end{abstract}

Index Terms-Downsizing, financial crisis, smis, productivity.

\section{INTRODUCTION}

The global financial crisis (GFC) has its effects on our economic growth, especially since the third quarter of 2008 . Among the most affected are the manufacturing industries and in particular the electrical and electronics industries. Multinational firms retrenched or announced downsizing plans as early as the end of 2008. Malaysia was worst hit the following year. As the impact of the global financial crisis would inevitably reach the local firms, their retrenching activities need to be studied. We need to know whether these retrenching activities have actually increased the labours' productivity. This outcome is crucial as retrenching is a measure that has to be taken in order to survive and sustain in the market. Due to contradicting results as reported in empirical studies, we need to ascertain the outcome in the case of Malaysian firms.

\section{LITERATURE REVIEW}

Retrenching or downsizing is defined as an intentional management action involving a reduction in personnel designed to improve a company's competitive position in

Manuscript received September 1, 2013; revised November 15, 2013. This work was supported by the Fundamental Research Grant Scheme, Ministry of Higher Education Malaysia, and Excellence Fund, Universiti Teknologi MARA Malaysia.

N. A. Ibrahim and R. Suhaimi are with the Department of Economics, Faculty of Business Management, Universiti Teknologi MARA Malaysia (e-mail: nurhani.ai@gmail.com, rositasu@sarawak.uitm.edu.my)

F. N. Chong is with the Department of Finance, Faculty of Business Management, Universiti Teknologi MARA Malaysia (e-mail: fenneechong@sarawak.uitm.edu.my) the market place [1], [2]. During the current global financial crisis, firms and corporations are searching for strategies to enable them to survive and sustain their profitability. These firms retrenched or retrench so that they can (a) reduce operating costs, (b) eliminates unnecessary level of management, (c) streamlines operations, (d) enables an organisation to prune deadwood, (e) enhances overall effectiveness, and (f) ultimately, makes a firm more competitive in today's market place [3]-[8] found that the evidence suggests retrenching is more likely to be effective when it is part of an organization's overall long-term strategic planning process.

However, retrenching can have negative effects on firms, such as (a) reducing profits, (b) slowing dividend growth, (c) lowering stock prices, (d) decreasing employees' morale and satisfaction, (e) increasing tardiness, absence, and turnover, and (f) escalating employees' workloads, stress, and companies' health care expenses [9]-[13]. In addition, [12] and [18] contend that retrenching disrupts or damages an organisation's ability to learn and adapt to the changing environment because the informal communication networks are adversely affected. [16] found that firms implementing retrenching tended to suffer more financial difficulties than their counterparts.

[17] point out that there are very few, if any, scientific data organisational leaders can point to that support the efficacy of this retrenching strategy. It may be due to the reasons that managers simply assume the overall benefits outweigh the cost, or they perceive that they have no alternative, i.e. if they do not cut costs immediately, their firms will not survive, or they simply jumped on the retrenching bandwagon as it complies to their quality circles and re-engineering requirements and so on. There has been a great deal of discussion concerning the efficacy of retrenching on firms' performance in the media and professional literature, however, there have been relatively few empirical studies or theoretical papers published in academic journals. For the purpose of this study, focus is given the economic theoretical perspective. From this perspective, managers are assumed to engage in retrenching to reduce organisational costs and hence, enhance financial performance [18], [19] found the changes in wages respond to changes in profits per employee and size of the firm. [20] found the productivity gap and differences in firm size are concentrated in the smallest and largest categories, the barriers faced by the smallest firms are unlikely to be the same as those faced by the largest firms.

Based on [21], collusion between workers and the manager in charge of retrenching induce more screening than in the absence of collusion if information asymmetry is large enough. According to this economic paradigm, 
organisational retrenching has a positive effect on a firm's financial performance, as it enables the management to eliminate redundancies, streamline operations, and reduce labour costs. However, [16] found that retrenching showed a positive effect by improving a firm's profitability and efficiency, but no effect on employee productivity. The economic literature is largely based on managerial and employees' perceptions of retrenching effectiveness. However, [22] found that employees did not perceive an improvement in the effectiveness of their company. On the contrary, they perceive a decline in production quality, quantity and employee morale. [23] found there is a great possibility for retrenching to be an unsuccessful firm's strategy and therefore to decrease the corporate reputation, it is important before making the decision about retrenching to reconsider the necessity of such a decision.

On the effect of retrenching on financial performance, [8] compare companies that announced layoffs with those that did not layoff and found that they do not differ financially during a period of one to two years prior to the announcement. Their t-tests revealed that the layoff firms had significantly lower profit margin, return on assets, return on equity and the market-to-book ratios during the announcement year and this increase in magnitude in the two years that follow. [24] found that companies laying off $10 \%$ or more of the work force significantly underperformed firms laying off less on profit margin, ROA, ROE, and market-to-book ratio. [8] found, the announced layoffs do not enhance financial performance. Based on [16] work, the improvement of financial performance (ROA) by retrenching was found to be greater among companies that had not experienced any loss than among those that had experienced loss. [25] shows that none of the financial variables were significantly affected following retrenching. Even during the pre-retrenching period, the financial variables were unrelated to the magnitude or frequency of retrenching activities. Based on [26], the survey evidence from managers involved suggests such decisions are not always based on financial information. However, [5] argued that as in several previous studies, the firm-level effects are the most important class of effect in explaining the variation in performance.

Ref. [27] found, although research on retrenching is growing, it is still dwarfed by the magnitude of this phenomenon in the marketplace. There are a host of theoretically and practically important issues in need of additional research. The organizational researchers need to apply relevant methodologies to these important and complex research questions.

\section{ReseARCh Methodology}

This study uses data on retrenchment in the manufacturing industries made available by the Ministry of Human Resource. The data are monthly statistics for 2009 till 2011 which covers retrenchment activities by state and industry, and reasons for retrenchment. This study also uses monthly data collected by the Department of Statistics (DOS), Malaysia, in their monthly manufacturing survey. Monthly data is used due to limited time dimension available for annual data, i.e. 2000 to 2007, and therefore cannot capture the effects of the recent global financial crisis. By using the monthly data, the time dimension is greatly enhanced from 7 years to 104 months as the monthly data are updated monthly whereas the yearly data are only available three years later. This is important to capture more time series in the panel data analysis. Furthermore, the monthly data would be able to capture the recession immediate effects on the firms' response to retrench. The data obtained from DOS are industries specified at 5-digit MSIC (Malaysian Standard of Industrial Classification) level and deflated to get their real values wherever necessary.

This study uses panel data analysis with fixed effects after performing the Hausman tests. The independent variables in the model are size, wage, and GFC. The dependent variable is labour productivity. Details of the variables are in the following section.

\section{FINDINGS AND DISCUSSION}

\section{A. Descriptive Statistics}

The descriptive statistics of the variables that has continuous values are given in Table I. Size is average size, which is measured by the number of paid employment divided by the number of establishments at 5-digit MSIC level. It has a mean of 336.50 and a standard deviation of 436.46. According to the table below, the average size of firms in each industry has a minimum of 9 paid workers and a maximum of 7667 paid workers. Wage is average wages, which is measured by the paid salaries divided by the number of labor. It has a mean of RM2, 500 and a standard deviation of RM4, 160. The workers earned a minimum average wages RM400 per month and a maximum of RM83, 800 per month.

TABLE I: DESCRIPTIVE STATISTICS

\begin{tabular}{cccccc}
\hline \hline Variable & Obs & Mean & $\begin{array}{c}\text { Std. } \\
\text { Dev. }\end{array}$ & Min & Max \\
\hline Size & 11856 & 336.5 & 436.4 & 9 & 7667 \\
Wage & 11856 & 2.5 & 4.2 & 0.4 & 83.8 \\
$\begin{array}{c}\text { Labour } \\
\text { Productivity }\end{array}$ & 11856 & 21.2 & 104.1 & -5316 & 1530.6 \\
\hline \hline
\end{tabular}

Labour productivity is measured by the real sales revenue minus raw material divided by the number of labor. It has a mean of 21.2 and a standard deviation of 104.1. According to the table above, the average labour productivity of firm in the industries has a minimum of -5316 and a maximum of 1530.6. The panel $\mathrm{f}$ all variables are strongly balanced with total observations of 11, o856. The dummy for GFC, which is not shown in the above table, are specified as 1 if Yes, 0 otherwise. GFC is identified as a period from October 2008 till December 2009 when the crisis actually occurred.

\section{B. Correlation}

The relationship between the labour productivity and average size is negative with a correlation coefficient (r) of 0.30 (See Table II). Even though it is significant at $5 \%$, but it indicates quite a weak relationship. The positive sign indicates that when labor productivity increases, average size tends to decrease. The relationship between the average wages and average size is negative with a correlation coefficient ( $r$ ) of -0.03 . The coefficient is very low. The 
negative sign indicates that as average wages increases, average size tends to increase. The relationship between the average wages and labor productivity is positive with a correlation coefficient (r) 0.10 . The positive sign indicates that on average wages increases, labor productivity tends to increase.

TABLE II: CORRELATION BETWEEN VARIABLES

\begin{tabular}{cccc}
\hline \hline & Size & $\begin{array}{c}\text { Labour } \\
\text { Productivity }\end{array}$ & Wages \\
\hline Size & 1.00 & & \\
Labour & -0.30 & 1.00 & \\
Productivity & 0.0011 & & \\
Wage & $-0.03^{*}$ & $0.10^{*}$ & 1.00 \\
\hline \hline
\end{tabular}

\section{Retrenchment Activities at State Level}

During the three years since the GFC faced by Malaysia, ie 2009 to 2011, the Ministry of Human Resource has recorded about 41,600 retrenchments in the manufacturing sector. The peak was in 2009 where $60 \%$ of all retrenchments during that period took place. This is not surprising as it was during 2009 that Malaysia faced its recession.

Compared to other states in Malaysia, Johore experienced the highest rate of retrenchment, with an average of $23.8 \%$ (9914) for all the three years. This is followed by Selangor with an average of $21.0 \%$ with 8721 retrenchments. This is followed by Penang at $17.6 \%$ with 7305 retrenchments, Kuala Lumpur at $10.4 \%$ with 4309 retrenchments, Perak at $7.1 \%$ with 2956 retrenchments and Malacca at $6.9 \%$ with 2890 retrenchments. Almost $98 \%$ of these retrenchments took place in the Peninsular Malaysia where most of the working population and industries are.

In East Malaysia, Sarawak experienced 1.6\% (664) out of total retrenchments during the same period. Much of the retrenchments, ie $44.3 \%$ out of the total 664 reported, took place in 2009. This excludes the retrenchments due to the closure of the Western Digital factory in December, 2008. Sabah, on the other hand, has $0.9 \%$ (370) out of total retrenchments, with almost $60 \%$ of them occurring in 2011 . The effect of the global financial crisis in Sabah seems rather belated. This may indicate the reluctance to retrench immediately following the onset of the crisis and the firms' ability to sustain with their current number of employees until 2011. While this is favourable to the affected workers, it may not be good for the industries as they have to bear higher cost of operation.

Manufacturing industries in Kelantan did most of their retrenching in 2010, instead of 2009 like most states. However, their retrenchments were still the lowest among all states, which was merely $0.6 \%$ (265) out of total retrenchments in the country's manufacturing sector. Various reports have shown that industries that are more export oriented tend to be more affected by the crisis. Therefore, states that have more export oriented industries are expected to resort to higher retrenchments compared to those that have less.

\section{Reasons for Retrenchments}

As the world was facing the GFC, most of the retrenchments were crisis-induced. This is evident from the survey on companies that retrenched workers during the period. More than half of them retrenched workers due to deteriorating demand of the product $(22.2 \%)$, drop in product market $(16.8 \%)$, no demand for product or services $(12.8 \%)$ and reduction in production $(1.8 \%)$. Another $10.2 \%$ companies specify their reason to retrench as due to high cost of production. This reason, in fact, is also induced by the global financial crisis because as sales fall, revenue falls and average cost increases, it is reducing the companies' profit margin or even incurring losses. Cost of production becomes too high to maintain. To sustain, reducing cost of production is inevitable. The most likely factor that will be adjusted is the variable factor, ie labour. Variable factors are factors that change with output.

During the same period, a total of 76 companies retrenched due to the sale of company, 49 companies retrenched due to closure and another 45 companies retrenched due to outsourcing their operation. Companies that are sold or closed tend to be companies that are not financially stable before their sale or closure. The global financial crisis did not help at all and the recession proves too challenging to sustain in the business. The natural option is to avoid or minimise their losses through closure or sale. Another 45 companies outsource some or part of their operation when production proves to be uneconomical to manage, especially when they failed to get the volume of sales that they need.

\section{E. Retrenchments in the Manufacturing Industries}

Out of the 23 main classifications of manufacturing industries, the radio, television and communication equipmnt and apparatus industries workers sufferred the highest retrenchments, with $26.9 \%$ (7106) out of the total of 26,381 . This is followed by rubber and plastic industries at $13.2 \%$ (3484), office, accounting and computing machinery industries at $7.7 \%$ (2.037), furniture, n.e.c. at $7.5 \%$ (1970), electrical machinery and apparatus, n.e.c. at $6.9 \%(1820)$ and other transport equipment ar 5.8\% (1539). The least affected industries with the lowest retrenchments (besides recycling) are core, refined petroleum products and nuclear with merely $0.1 \%$ (16) out of total retrenchmments, tanning and dressing of leather and related industries at $0.2 \%$ (55) and tobacco product at $0.5 \%$ (138).

\section{F. Effect of Downsizing and GFC on Labour Productivity}

To analyse the effect of GFC and downsizing on labour productivity, three models were run as shown in Table III. Average size is included in the models to capture both the downsizing and recruiting effect on SMIs' labour productivity. To check for robustness, the study analyses the industries by their relative sizes by dividing total observations into three categories, ie small industries (SIs), small and medium industries (SMIs) and large industries (LIs). The industries are specified as SIs if their average employment (L) is $\leq 150$, SMIs if $\mathrm{L} \leq 300$ and LIs if $\mathrm{L}>300$. The normal definition of SMEs which state their number of employment of $\leq 75$ workers cannot be applied here because it will significantly reduce the number of industries specified under SMIs. Instead, the study decides on the range of emloyment to have a more evenly distributed number of observations among the small, medium and large industries. See Table III. 
It should be noted that downsizing activities did not only occured during the GFC but there were rather scatterred at different periods for different industries. As some firms retrenched the workers during the GFC, others continued to recruit workers despite the crisis. To capture the effect of GFC, the GFC dummy is included in the models. Average wage is included in the model as a control variable.

TABLE III: DETERMINANTS OF LABOUR PRODUCTIVITY BY SIZE OF

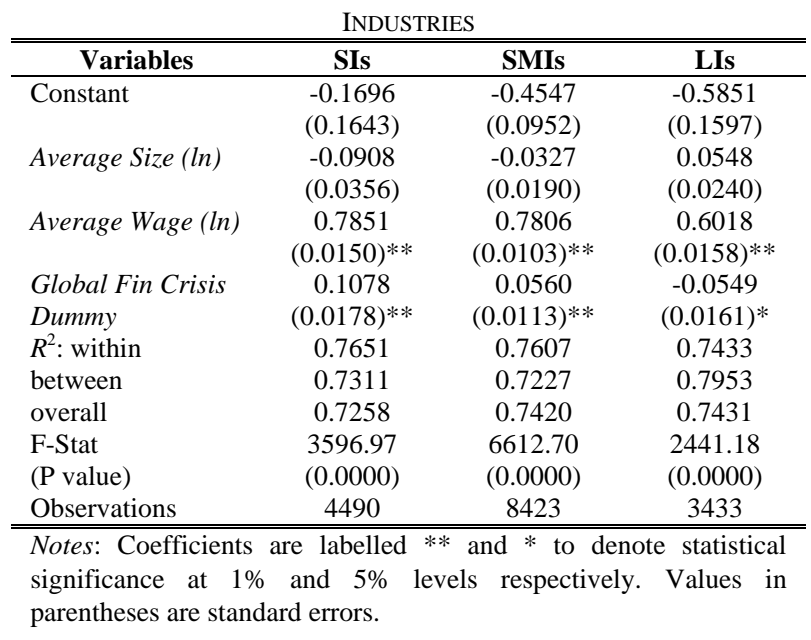

Downsizing is found to be insignificant in determining labour productivity of SMIs. This means that the firms reduced their workers not to improve labour productivity but rather to adjust to the current demand for their product as discussed in the earlier subsection on reasons for retrenchments. Size is found to be insignificant in influencing labour productivity. This means that the industries activities of recruiting and retrenching do not significantly affect their labour productivity regardless of their size. This may also indicate insignificant shift in the method of production from labour intensive to capital intensive. The shift may have taken place in some firms for some industries, but generally, during the period 2003-2011 covered in the study, they are not significant. It is also found that, during the 2009-2011 period, only $0.5 \%$ (12) of total retrenchments was due to the shift to automated system. This shows that the effect of the shift on employment was minimal during this period. In fact, in industries that rely substantially on foreign workers, the shift is highly encouraged to reduce our reliance on them. With the implementation of the minimum wage order which will be enforced on 1 January, 2013 for most firms in all sectors, shifting to automated system or other more effective methods that will create higher value added should be the order of the day, if Malaysia is to become a high income economy by 2020 .

GFC is found to have a positive significant effect on the labour productivity of SMIs but a negative effect on labour productivity of the LIs. The GFC variable captures the period from the fourth quarter of 2008 to the fourth quarter in 2009, when the crisis actually set in. Due to the concern that arised during the economic crisis and the possible threat of downsizings, the SMIs workers may have been motivated to work harder to help their company and themselves to go through the crisis proactively. The economic stimulus packages announced in November 2008 and February 2009 may have assisted the industries to a certain extent. This may not be the case with the LIs.

This study provides evidence that the SMIs are generally able to cope well during the GFC, whereas the LIs are badly affected by the GFC. Possibly, due to their relatively smaller size, the SMIs are more flexible in making adjustments to their production and business strategy during the crisis. The LIs, on the other hand, have rather limited ability to make similar adjustments, therefore, causing a negative effect on them.

\section{CONCLUSION}

This paper analyses retrenchment activites in the recent years since the onset of the GFC. Retrenchments are particularly high in 2009 for most states, whereas others have a belated effect in 2010 and 2011 instead. The main reasons for the retrenchments are related to the GFC which has brought Malaysia into recession in 2009. Two main subsectors most affected were the manufacture of radio, televison and communication equipment and apparatus, and manufacture of rubber and plastic products.

In examining the effect of downsizing and GFC on labour productivity, the study provides evidence that downsizing has positive significant effect on labour productivity of the SMIs. On the contrary, the LIs are negatively affected by the GFC. These results provides insights to what happened during the global financial crisis within the scope of this study. Inevitably, there are still a lot that the industries need to initiate to ensure their firms can enjoy from higher value added products. Creating higher value added products and services will put the economy in the right path towards achieving a high income economy status by 2020 .

\section{ACKNOWLEDGMENT}

We would like to acknowledge funding from FRGS and Excellence Fund to complete the research.

\section{REFERENCES}

[1] T. M. Amabile and R. Conti, "Changes in the work environment for creativity during downsizing," Academy of Management Journal, vol. 42 , pp. 630, 1999.

[2] S. J. Freeman and K. S. Cameron, "Organizational downsizing: A convergence and reorientation framework," Organization Science, vol. 4, no. 1, pp. 10-29, 1993 .

[3] J. A. Byrne, "There is an upside to downsizing," Business Week, vol. 9, pp. 69, May 1994.

[4] G. Fuchsberg, "Why shakeups work for some, not for others," The Wall Street Journal, B1, B5, October 1993.

[5] J. Goddard, M. Tavakoli, and J. O. S. Wilson, "Sources of variation in firm profitability and Growth," Journal of Business Research, vol. 62, pp. 495-508, 2007

[6] S. Collins and D. Rodrik, "Catalyst, not saviors," The Economist, vol. 21, pp. 24-26, September 1991

[7] W. Kinley, C. M. Sanchez, and A. G. Schick, "Organizational downsizing: Constraining, cloning, learning," Academy of Management Executive, vol. 9, no. 5, pp. 121-145, 1995.

[8] K. P. D. Meuse, P. A. Vanderheiden, and T. J. Bergmann, "Announced layoffs: Their effect on corporate financial performance," Human Resource Management, vol. 33, pp. 509-530, 1994.

[9] R. B. Reich, "Companies are cutting their hearts out," The New York Times Magazine, pp. 54-55, December 191993.

[10] D. L. Worrell, W. N. III. Davidson, and V. M. Sharma, "Layoff announcements and stockholder wealth," Academy of Management Journal, pp. 662-678, 1991. 
[11] A. K. Mishra and G. M. Spreitzer, "Explaining how survivors respond to downsizing: The roles of trust, empowerment, justice, and work redesign," Academy of Management Review, vol. 23, pp. 567-588, 1998.

[12] D. M. Noer, Healing the Wounds: Overcoming the Trauma of Layoffs and Revitalizing Downsized Organizations, San Francisco, CA: Jossey-Bass, 1993.

[13] J. Pfeffer, The Human Equation: Building Profits by Putting People First, Boston, MA: Harvard Business School Press, 1998.

[14] S. R. Fisher and M. A. White, "Downsizing in a learning organization: Are there hidden costs?" Academy of Management Review, vol. 25, pp. 244-251, 2000

[15] D. Lei and M. A. Hitt, "Strategic restructuring and outsourcing: The effect of mergers and acquisitions and LBOs on building firm skills and capabilities," Journal of Management, vol. 21, pp. 835-859, 1995.

[16] G. C. Yu and J. S. Park, "The effect of downsizing on the financial performance and employee productivity of Korean firms," International Journal of Manpower, vol. 27, no. 3, pp. 230-250, 2005.

[17] K. P. D. Meuse and M. L. Marks, Resizing the Organisation: Managing Layoffs, Divestitures and Closings, San Francisco, CA: Jossey, 2003

[18] W. Kinley, J. Zhao, and K. G. Rust, "A sociocognitive interpretation of organizational downsizing," Journal of Management Review, vol. 25 , pp. 227-243, 2000.

[19] M. Söderbom, F. Teal, and A. Wambugu, "Does firm size really affect earnings?" CSAE Working Paper Series 2002-08, Centre for the Study of African Economies, University of Oxford, 2002.

[20] D. Leung, C. Meh, and Y. Terajima, "Firm Size and Productivity," Working Paper 2008-45, Bank of Canada, 2008.

[21] A. Estache, J. Laffont, and X. Zhang, "Downsizing with labor sharing and collusion," Journal of Development Economics, vol. 73, no. 2, pp. 519-540, April 2004.

[22] K. S. Cameron, S. J. Freeman, and A. K Mishra, "Best practices in white-collar downsizing: Managing contradictions," Academy of Management Executive, vol. 5, pp. 57-73, 1991.

[23] B. Djordjević and S. Djukić, "The impact of downsizing on the corporate reputation," Facta Universitatis, Economics and Organisation Series, vol. 5, no. 1, pp. 51-62, 2008.

[24] K. P. D. Meuse, T. J Bergmann, P. A. Vanderheiden, and C. E. Roraff, "New evidence regarding organizational downsizing and a firm's financial performance: A long-term analysis," Journal of Managerial Issues, vol. 60, pp. 155-177, 2004.

[25] W. F. Cascio, "Learning from outcomes: Financial experiences of 311 firms that have downsized," in The New Organisational Reality:
Downsizing, Restructuring, and Revitalisation, Eds M. K. Gowing, J. D. Fraft, and J. C. Quick, Washington, DC: American Psychological Association, 1998, pp. 55.

[26] J. D. Kirkham, S. M. Richbell, and H. D. Watts, "Downsizing and facility location: plant closures in multiplant manufacturing firms," Management Decision, vol. 36, no. 3, pp. 189-197, 1998.

[27] D. K. Datta, J. P. Guthrie, D. Basuil, and A. Pandey, "Causes and effects of employee downsizing: A review and synthesis," Journal of Management, vol. 36, no. 1, pp. 281-348, 2010.

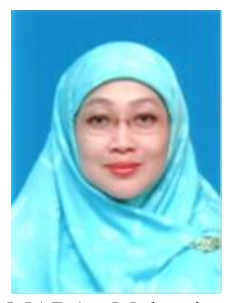

Nurhani Aba Ibrahim is a technical committee member for the National Wage Consultative Council of Malaysian since 2011. The committee is responsible to conduct various studies on labour, wages, and minimum wages and write occasional reports on the implementation of minimum wage in Malaysia. She obtained her PhD in Economics from the University of Leicester, UK (2007), Master of Business Administration from Universiti Teknologi MARA, Malaysia (1999) and Bachelor of Economics (Hons) from the International Islamic University, Malaysia.

She is a senior lecturer at the Department of Economics, Faculty of Business Management, Universiti Teknologi MARA (UiTM), Samarahan Campus, Sarawak, Malaysia. She has more than 20 years of teaching experience at the university. She was also a Coordinator for the UiTMIndustry Linkages Centre at the same campus (2009-2011). She had supervised six MSc Finance students at the School of Management, University of Leicester (2005-2006) and currently supervises three $\mathrm{PhD}$ and two master by research students at the Universiti Teknologi MARA. She was the lead researcher for a Fundamental Research Grant Scheme titled "The Causality of Economic Stimulus Packages and Downsizing on the Productivity and Profitability of Manufacturing Firms in Malaysia" which was recently completed in 2013. She has co-authored books, including Strategic Industrialization Programmes and Database for Small and Medium Industries (SMIs) in Sarawak, Volume 1 \& 2, (Sarawak, Malaysia: Ministry of Industrial Development, 1996) and Business and Market Opportunities for Bumiputera Entrepreneurs in Kuching Division, (Sarawak, Malaysia: DUBS, 1995). Her recent article publication is "Causality between Exports and Productivity in the Malaysian Economy" Singapore Economic Review, Vol. 56. No.3 (2011).

Dr. Nurhani is also a panel evaluator (Economics) for the Malaysian Qualifying Agency, member of the Royal Economic Society, Economics Association of Malaysia and Social Science Association of Malaysia. 